\title{
HUBUNGAN STATUS IMUNISASI DAN PERAN PETUGAS IMUNISASI DENGAN KEJADIAN CAMPAK DI KABUPATEN MUNA
}

\author{
"Wa ode Fera Falawati, Timbul Supodo, Sunarsih \\ Magister Kesehatan Masyarakat, STIKES Mandala Waluya, *waode_fera@yahoo.com
}

\begin{abstract}
INFO ARTIKEL
Riwayat Artikel:

Diterima: 23-08-2019

Disetujui: 24-09-2019

\section{Kata Kunci:}

Campak

Status Imunisasi

Peran Petugas

Anak-anak

Penyakit

ABSTRAK

Abstrak: Campak merupakan salah satu penyakit menular yang masih menjadi masalah kesehatan dan banyak terjadi pada bayi dan anak. Terjadi kejadian luar biasa (KLB) campak di Kabupaten Muna di beberapa wilayah Puskesmas pada tahun 2017 dan banyak menyerang anak-anak. Tujuan: Penelitian adalah untuk mengetahui hubungan antara status imunisasi dan peran petugas imunisasi dengan kejadian campak di Kabupaten Muna. Metode: Jenis penelitian ini adalah kuantitatif dengan desain case control. Populasi adalah semua penderita campak tahun 2017. Sampel dalam penelitian ini adalah 95 kasus dan 95 kontrol. Data dikumpulkan dengan menggunakan kuisioner, wawancara dan dianalisis secara deskriptif, inferensial dan epidemiologi. Hasil : Hasil penelitian diperoleh bahwa status imunisasi berhubungan dengan kejadian campak di Kabupaten Muna dimana $X^{2}$ hitung $>X^{2}$ tabel $(62,043>3,841)$, dengan OR: 29,963; C195\%; 10,171- 88,274, dan peran petugas imunisasi tidak berhubungan dengan kejadian campak di kabupaten muna dimana diperoleh nilai $x^{2}$ hitung $<x^{2}$ tabel $(1,604<3,841)$ dengan OR: 0,635; CI95\%: 0,339-1,188. Kesimpulan: Terdapat hubungan hubungan status imunisasi dan peran petugas imunisasi dengan kejadian campak di kabupaten Muna
\end{abstract}

\begin{abstract}
Measles is one of the infectious diseases that is still a health problem, and many occur in infants and children. The outbreak measles occurred in Muna district in several areas of society health centre in 2017 and many attacked children. Objective: This research is to know the relationship between immunization status and the role of immunization officers with the occurrence of measles in Muna district. Method: This type of research is quantitative which is a case control design. The population is all patients with measles in 2017. The samples in this study were 95 cases and 95 controls. Data is collected using questionnaire, interviews and analysed in a descriptive, inferential and epidemiological basis. Results: The results of the study were obtained that the immunization status relates to measles occurrences in Muna district where X2 counts > X2 table (62.043 > 3.841), with OR: 29.963; C195\%; 10.171-88.274, and the role of immunization officers is not associated with the occurrence of measles in Muna district where the value of X2 count the calculated $<$ X2 table $(1.604<3.841)$ with OR: 0.635; C195\%: 0,339-1,188. Conclusion: There is a relationship between immunization status and the role of immunization officers with measles events in Muna district.
\end{abstract}

\section{A. LATAR BELAKANG}

Campak adalah penyakit yang menyerang manusia dan sangat menular yang ditandai oleh beberapa gejala akut yaitu demam tinggi, konjungtivitis, coryza, batuk dan ruam makulo papular.Dapat mengakibatkan penyakit serius dengan komplikasi berat, termasuk pneumonia, ensefalitis dan kematian (Tramuto et al., 2018).

Campak adalah penyakit infeksi sistemik yang dimulai infeksi pada bagian epitel saluran pernafasan di nasopharing, virus campak dikeluarkan dari nasopharing mulai dari masa prodromal sampai 3 - 4 hari setelah rash (Arianto, Setiawati, Adi, Hadisaputro, \& Budhi, 2018).

Penyebab infeksi adalah virus campak, anggota genus Morbilivirus dari famili Paramyxoviridae(Halim, 2016). Penderita campak sebagian besar akan sembuh, sering terjadi komplikasi pada anak usia $<5$ tahun dan penderita dewasa usia > 20 tahun(Indonesia, 2012). Penderita campak dengan gizi buruk dan defisiensi vitamin A serta immune deficiency (HIV), komplikasi campak dapat menjadi lebih berat atau fatal(Liwu, Rampengan, \& Tatura, 2016). Komplikasi yang sering terjadi yaitu : diare, broncho pneumonia, malnutrisi, otitis media, kebutaan, encephalitis, ulkus mucosa mulut(Astuti \& Hartini, 2017).

Center dor Desease Control (CDC) 2013 menyatakan bahwa World Health Asembly (WHA) pada bulan Mei 2010 menyepakati target pencapaian pengendalian penyakit campak pada tahun 2015 yaitu mencapai cakupan imunisasi campak dosis pertama $>90 \%$ secara nasional dan minimal $80 \%$ di seluruh Kabupaten dan Kota. Menurunkan angka insiden campak menjadi $<5 / 1$.000.00o setiap tahun dan mempertahankannya. Menurunkan angka kematian tahun 2000 (CDC, 2013).

Campak dapat menjadi masalah yang serius untuk semua kelompok umur, namun anak dengan umur 5 
sampai dengan 20 tahun berisiko menderita komplikasi penyakit campak (CDC, 2018). Case Fatality Rate (CFR) penderita campak di negara berkembang sebesar 3-5\% tetapi sering kali di beberapa lokasi berkisar antara 10\%$30 \%$. Anak-anak dengan status gizi kurang dan buruk, campak seringkali sebagai penyebab terjadinya kwasiorkor akut dan eksaserbasi defisiensi vitamin A yang dapat menyebabkan kebutaan (Masriadi, 2017).

Berdasarkan laporan Case Based Measles Surveilans (CBMS) atau kegiatan surveilans campak berbasis individu, di Indonesia lebih dari 11.000 kasus suspek campak dan setelah dilakukan pemeriksaan laboratorium, $12-39 \%$ hasilnya adalah positif campak (lab confirmed). Dari tahun 2010 sampai 2015, diperkirakan terdapat 23.164 kasus campak, akan tetapi masih banyak kasuskasus campak yang belum terlaporkan terutama yang berobat di Rumah Sakit dan pelayanan swasta karena saat ini belum ada sistim pelaporan terpadu antara Rumah Sakit dan pelayanan swasta ke Dinas Kesehatan baik di Kabupaten maupun di Provinsi (Kemenkes., 2017).

Pada tahun 2017 suspek campak menyebar hampir di seluruh provinsi Indonesia, dilaporkan terdapat 15.104 kasus suspek campak, lebih tinggi di bandingkan tahun 2016 yaitu sebesar 12.681 kasus (Kemenkes, 2018).

Rencana strategi Kementerian Kesehatan tahun 2015-2019 adalah Program Indonesia Sehat yaitu meningkatkan kualitas hidup masyarakat Indonesia. Tujuan utama dari Program Indonesia sehat adalah meningkatkan status kesehatan dan gizi masyarakat dengan pemberdayaan masyarakat yang ditunjang dengan ekonomi yang baik dan pemeratan sarana kesehatan (Kemenkes-, 2015). Tahun 2017 terjadi Kejadian Luar Biasa (KLB) campak yaitu di wilayah Puskesmas Katobu, Kabawo, Tampo dan Lasalepa dengan total 142 kasus. KLB campak terjadi dua tahun di Kabupaten Muna yaitu pada tahun 2016 dan 2017 (Dinkes.Kabupaten.Muna, 2018).

Berdasarkan latar belakang tersebut, sehingga peneliti tertarik melakukan penelitian tentang hubungan status imunisasi dan peran petugas imunisasi dengankejadian campak di kabupaten Muna.

\section{B. METODE PENELITIAN}

Jenis penelitian ini adalah kuantitatif, mengguna kanrancangan case control study dengan pendekatan retrospektif (Sumantri, 2015). Penelitian ini dilakukan di Kabupaten Muna. Populasi dalam penelitian ini adalah penderita campak pada tahun 2017 berjumlah 142 orang. Adapun Sampel kasus sebanyak 95 orang, teknik pengambilan sampel dalam penelitian ini menggunakan simple random sampling, diambil secara acak dari semua penderita dan sampel kontrol sebanyak 95 orang dengan matching umur dan jenis kelamin. Dengan demikian didapatkan total sampel sebanyak 190 orang.

Data diperoleh melalui wawancara dengan menggunakan kuesioner terhadap sampel kasus dan control (Juliansyah Noor, 2016).Analisis data dilakukan dalam tiga tahap yaitu analisis deskriptif, analisis inferensial dan analisis epidemiologi. Penelitian ini telah mendapatkan izin penelitian dari Badan Penelitian dan Pengembangan, Sulawesi Tenggara dengan nomor persetujuan: 070/0857 /BALITBANG / 2019.

\section{HASIL DAN PEMBAHASAN}

Hasil penelitian ini menggambarkan faktor risiko kejadian campak di Kabupaten Muna berdasarkan status imunisasi campak pada anak yang dapat dilihat pada tabel 1 dan 2 serta peran aktif petugas dalam pelayanan imunisasi dapat dilihat pada tabel 3 dan 4 .

\section{Analisis hubungan status imunisasi dengan Kejadian Campak}

TABEL 1.

Distribusi Status Imunisasi Campak di Kabupaten Muna

\begin{tabular}{lll}
\hline \multirow{2}{*}{ Status Imunisasi } & \multicolumn{2}{c}{ Jumlah } \\
\cline { 2 - 3 } & $\mathrm{n}$ & $\%$ \\
\hline Tidak & 58 & $30.5 \%$ \\
Ya & 132 & $69.5 \%$ \\
Jumlah & 190 & $100.0 \%$ \\
\hline
\end{tabular}

Berdasarkan tabel 1 menunjukkan bahwa dari sampel sebanyak 190 responden, yang tidak mendapatkan imunisasi campak sebanyak 58 anak (30,5\%) dan yang mendapat imunisasi campak sebanyak 132 anak (69,9\%).

TABEL 2.

Distribusi Status Imunisasi dengan Kejadian Campak di Kabupaten Muna

\begin{tabular}{|c|c|c|c|c|c|c|c|c|c|c|c|}
\hline \multirow{3}{*}{$\begin{array}{l}\text { Stat } \\
\text { us } \\
\text { Imu } \\
\text { nisa } \\
\text { si }\end{array}$} & & adia & $\mathrm{Ca}$ & npa & & & \multirow{3}{*}{$\begin{array}{l}\mathrm{X}^{2} \\
\text { Hit } \\
\text { un } \\
\mathrm{g}\end{array}$} & \multirow{3}{*}{$\begin{array}{l}P h \\
i( \\
\Phi)\end{array}$} & \multirow[t]{3}{*}{ OR } & \multicolumn{2}{|c|}{$\begin{array}{l}9596 \mathrm{Con} \\
\text { fidence } \\
\text { Interval } \\
\text { (CI) }\end{array}$} \\
\hline & \multicolumn{2}{|c|}{ Kasus } & \multicolumn{2}{|c|}{$\begin{array}{l}\text { Kontr } \\
\text { ol }\end{array}$} & \multicolumn{2}{|c|}{$\begin{array}{l}\text { Jumla } \\
\mathrm{h}\end{array}$} & & & & $\begin{array}{l}\text { Lo } \\
\text { we }\end{array}$ & Up \\
\hline & $\mathrm{N}$ & 96 & $\mathrm{~N}$ & 96 & $\mathrm{n}$ & 96 & & & & $\mathrm{r}$ & \\
\hline $\begin{array}{l}\text { Tida } \\
\mathrm{k}\end{array}$ & $\begin{array}{l}5 \\
4\end{array}$ & $\begin{array}{l}93 \\
1 \\
96\end{array}$ & 4 & $\begin{array}{l}6 \\
9 \\
96\end{array}$ & $\begin{array}{l}5 \\
8\end{array}$ & $\begin{array}{l}10 \\
0 \\
96\end{array}$ & & & & & \\
\hline $\mathrm{Ya}$ & $\begin{array}{l}4 \\
1\end{array}$ & $\begin{array}{l}31 \\
, 1 \\
96 \\
\end{array}$ & $\begin{array}{l}9 \\
1\end{array}$ & $\begin{array}{l}68 \\
9 \\
96\end{array}$ & $\begin{array}{l}1 \\
3 \\
2 \\
\end{array}$ & $\begin{array}{l}10 \\
0 \\
96\end{array}$ & $\begin{array}{l}59 \\
58 \\
6\end{array}$ & $\begin{array}{l}0,5 \\
71\end{array}$ & $\begin{array}{l}29 \\
96 \\
3\end{array}$ & $\begin{array}{l}10, \\
17 \\
1\end{array}$ & $\begin{array}{l}88, \\
27 \\
4\end{array}$ \\
\hline $\begin{array}{l}\text { Jum } \\
\text { lah }\end{array}$ & $\begin{array}{l}9 \\
5\end{array}$ & $\begin{array}{l}50 \\
96\end{array}$ & $\begin{array}{l}9 \\
5\end{array}$ & $\begin{array}{l}50 \\
96\end{array}$ & $\begin{array}{l}1 \\
9 \\
0\end{array}$ & $\begin{array}{l}10 \\
0 \\
96\end{array}$ & & & & & \\
\hline
\end{tabular}

Berdasarkan tabel 2, menunjukkan bahwa dari 58 sampel yang tidak di imunisasi terdapat 54 anak (93,1\%) menderita campak dan 4 anak $(6,9 \%)$ yang tidak menderita campak. Sedangkan dari 132 anak yang sudah mendapatkan imunisasi terdapat 41 anak $(31,1 \%)$ menderita campak dan 91 anak $(68,9 \%)$ tidak menderita campak.

Berdasarkan hasil uji statistik dengan menggunakan analisis Chi Square pada $\alpha=5 \%$ dan $\mathrm{df}=1$, diperoleh nilai $\mathrm{X}^{2}$ hitung $>\mathrm{X}^{2}$ tabel $(62,043>$ 3,841 ), artinya terdapat hubungan antara status imunisasi dengan kejadian campak di Kabupaten 
Muna. Hasil uji keeratan hubungan menunjukkan koefisien Phi $(\Phi)$ sebesar 0,571, hal ini menunjukkan kekuatan hubungan antara status imunisasi dengan kejadian campak di Kabupaten Muna kategori hubungan kuat.

Berdasarkan perhitungan Odds Ratio (OR) statusimunisasi terhadap kejadian campak pada tingkat (CI) $95 \%$, diperoleh OR sebesar 29,963. Ini berarti Anak yang tidak diimunisasi mempunyai risiko 29,8 kali lebih besar untuk menderita campak dibandingkan dengan anak yang diimunisasi campak (95\% CI : 10,171 - 88,274). Secara statistik bermakna dimana 95\% CI tidak melewati (tidak kurang) dari nilai satu.Sehingga orang yang tidak diimunisasi campak dapat dianggap berpotensial sebagai faktor risiko kejadian campak.

\section{Analisis Hubungan Peran Petugas dengan Kejadian campak}

TABEL 3.

Distribusi Peran Petugas Imunisasi di Kabupaten Muna

\begin{tabular}{lll}
\hline \multirow{2}{*}{ Peran Petugas } & \multicolumn{2}{c}{ Jumlah } \\
\cline { 2 - 3 } & $\mathrm{n}$ & $\%$ \\
\hline Tidak Aktif & 57 & $30 \%$ \\
Aktif & 133 & $70 \%$ \\
Jumlah & 190 & $100 \%$ \\
\hline
\end{tabular}

Tabel 3 menunjukkan bahwa dari 190 responden terdapat 57 responden (30\%) yang menyatakan peran petugas tidak aktif dan 133 responden (70\%) yang menyatakan aktif.

TABEL 4 .

Analisis Hubungan Peran Petugas dengan Kejadian Campak di Kabupaten Muna

\begin{tabular}{|c|c|c|c|c|c|c|c|c|}
\hline \multirow{3}{*}{$\begin{array}{l}\text { Pern } \\
\text { Pesturas }\end{array}$} & \multicolumn{5}{|c|}{ Tyiditiacamoh } & \multirow{3}{*}{ - Bing } & \multirow{3}{*}{ 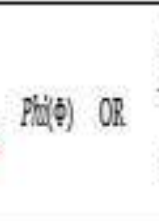 } & \multirow{3}{*}{$\begin{array}{l}\text { 95\% Confidence } \\
\text { Interve(CI) } \\
\text { Loner Opper }\end{array}$} \\
\hline & \multicolumn{2}{|c|}{ Z8OS } & Inotol & \multicolumn{2}{|c|}{ Inmah } & & & \\
\hline & $y$ & S & 18 & $\mathbb{1}$ & 8 & & & \\
\hline Tialastiff & 24 & $42,1 \%$ & 3355.96 & 57 & $100 \%$ & & & \\
\hline Axifif & 71 & $534 \%$ & $62 \quad 46.60 \%$ & 133 & $100 \%$ & 1604 & $0,103 \quad 0,635$ & $0,339 \quad 1,88$ \\
\hline Jumlah & 95 & 506 & $95 \quad 506$ & 190 & 1006 & & & \\
\hline
\end{tabular}

Tabel 4 menunjukkan bahwa dari 57 responden yang menyatakan peran petugas imunisasi tidak aktif terdapat 24 responden (42,1\%) yang anaknya menderita campak dan 33 responden (57,9\%) tidak menderita campak. Sedangkan dari 133 responden yang menyatakan peran petugas aktif terdapat 71 responden $(53,4 \%)$ yang menderita campak dan 62 responden $(46,6 \%)$ yang tidak menderita campak.

Berdasarkan hasil uji statistik dengan menggunakan analisis Chi Square pada $\alpha=5 \%$ dan df
$=1$, diperoleh nilai $\mathrm{X}^{2}$ hitung $<\mathrm{X}^{2}$ tabel $(1,604<$ 3,841 ),artinya tidak terdapat hubungan antara peran petugas dengan kejadian campak di Kabupaten Muna. Karena tidak terdapat hubungan antara peran petugas dengan kejadian campak maka tidak dilanjutkan ke uji keeratan hubungan.

Berdasarkan perhitungan Odds Ratio (OR) peran petugas terhadap kejadian campak pada tingkat (CI) $95 \%$, diperoleh OR sebesar 0,635. Ini berarti peran petugas bukan merupakan faktor risiko dari kejadian campak di Kabupaten Muna.

\section{DISKUSI}

\section{Hubungan Status Imunisasi Dengan Kejadian Campak}

Cakupan imunisasi sangat erat kaitannya dengan status imunisasi pada anak, berdasarkan data yang dilaporkan bahwa cakupan imunisasi campak di Kabupaten Muna belum mencapai standar nasional yang ditetapkan oleh Kementrian Kesehatan yaitu $95 \%$, sehingga kekebalan anak yang mendapatkan imunisasi tidak dapat melindungi populasi anakanak yang rentan.

Hasil penelitian ini menunjukkan bahwa dari 58responden anak yang tidak di imunisasi terdapat 54 anak (93,1\%\%) yang menderita campak, hal ini disebabkan karena anak tidak mempunyai sistim kekebalan tubuh terhadap penyakit campak.

Sedangkan dari 132 anak yang sudah mendapatkan imunisasi terdapat 41 anak (31,1\%) yang menderita campak, hal ini disebabkan karena pengaruh kualitas dan efikasi vaksin. Kualitas vaksin sangat dipengaruhi oleh coldchain dan rantai dingin vaksin.Berdasarkan hasil wawancara dengan petugas imunisasi bahwa sebelum menggunakan choldchain yang sesuai standar, puskesmas menyimpan vaksin pada coldchain yang menggunakan sumbu.Coldchain yang menggunakan sumbu, suhunya tidak stabil dan kadang melebihi dari $8^{\circ} \mathrm{C}$.

Efikasi vaksin campak pada anak yang mendapatkan vaksin di usia 9 bulan $>85 \%$, sehingga masih terdapat anak-anak yang belum memiliki kekebalan dan menjadi kelompok rentan terhadap penyakit campak. Untuk mendapatkan kekebalan secara optimal terhadap penyakit campak seorang anak harus mendapatkan minimal tiga dosis imunisasi yang diberikan pada umur 9 bulan, 18 bulan dan saat usia sekolah dasar kelas satu (Kesehatan, 2005).

Dari 58 responden yang anak yang tidak di imunisasi juga terdapat empat anak (6,9\%) yang tidak menderita campak, hal ini dapat disebabkan karena anak memiliki kekebalan yang didapatkan secara alamiah dari ibu terutama pada anak-anak yang mendapatkan ASI sampai dengan usia dua tahun serta adapula anak yang memiliki kekebalan aktif yaitu perlindungan yang yang diperoleh dari 
dalam tubuh anak tersebut dimana kekebalan ini akan bertahan seumur hidup.

Dari 132 anak yang sudah mendapatkan imunisasi juga terdapat 91 anak $(68,9 \%)$ yang mendapatkan imunisasi dan tidak menderita campak hal ini disebabkan karena anak mempunyai kekebalan yang berasal dari vaksin hal ini sejalan dengan teori, Imunisasi campak bertujuan memberikan kekebalan seseorang terhadap penyakit campak dengan membentuk antibody dengan kadar tertentu.

Hasil analisis statistik menunjukkan bahwa ada hubungan status imunisasi dengan kejadian campak di Kabupaten Muna dengan Odds Ratio (OR) = 29,963 yaitu anak yang tidak di imunisasi campak berisiko 29, 963 kali lebih besar menderita campak dibanding dengan anak yang mendapatkan imunisasi campak. Dalam penentuan status imunisasi dapat terjadi bias informasi karena hanya berdasarkan ingatan responden bukan berdasarkan KMS atau catatan kohor petugas imunisasi.

Hasil penelitian yang sama yang dilakukan oleh Mujiati Tahun 2015 menunjukkan secara statistik bahwa status imunisasi berpengaruh terhadap kejadian campak ( $p$ value 0,024$)$. Nilai OR yang diperoleh sebesar 3,0 (IK 95\% 1,242-7,464) yang artinya anak yang belum diimunisasi beresiko 3,o kali untuk mengalami kejadian campak dibandingkan dengan anak yang sudah diimunisasi. (Mujiati, Mutahar, \& Rahmiwati, 2015). Penelitian lainnya yang sejalan dilakukan oleh Giasrawan menjelaskan bahwa status imunisasi yang tidak lengkap pada anak berisiko 16 kali mempengaruhi terjadinya kasus campak. (Giarsawan, Asmara, \& Yulianti, 2014).

Imunisasi campak yang didapatkan pada usia sembilan bulan adalag cara paling efektif untuk mencegah terjadinya penyakit campak pada anak. Vaksin campak berasal dari virus hidup yang dilemahkan. Pemberian vaksin dengan intrakutan atau intra muskular dengan dosis $0,5 \mathrm{cc}$. pemberian imunisasi campak satu kali akan memberikan kekebalan selama 14tahun, sedangkan untuk mengendalikan penyakit diperlukan cakupan imunisasi paling sedikit $80 \%$ per wilayah secara merata selama bertahun-tahun (Irianto, 2014).

Penelitian lainnya yang sejalan dengan penelitian ini, setelah dilakukan ujistatistic dengan uji chisquare didapatkanhasil $\mathrm{p}=0,000(\mathrm{p}<0,05)$, ini berarti bahwa ada hubungan status imunisasi dengan kejadian campak pada anak usia balita diKota Bukittinggi Tahun 2016. Hasil analisis lanjut diperoleh nilai Odds Ratio 10,704, dapat diartikan bahwa responden yang tidak diberikan imunisasi campak, berpeluang 10,7 kali untuk terjadi campak, dibandingkan dengan responden yang diberikan imunisasi campak (Harisnal \& Ediana, 2019).

\section{Hubungan Peran Petugas Dengan Kejadian Campak}

Peran petugas sangat diharapkan selain dalam meningkatkan cakupan imunisasi juga memberikan informasi dan sosialisasi tentang manfaat imunisasi dan penyakit dapat dicegah dengan imunisasi .Untuk mencegah kejadian campak, petugas imunisasi dapat berperan aktif dalam pemberian imunisasi campak.

Hasil penelitian ini menunjukkan bahwa dari 133 responden yang menyatakan peran petugas imunisasi aktif terdapat 71 responden $(53,4 \%)$ yang mempunyai anak menderita campak hal ini di sebabkan karena beberapa faktor diantaranya dalam pelaksanaan imunisasi rutin setiap bulan sering dilaksanakan diluar ruangan sehingga mempengaruhi potensi vaksin, serta saat pengambilan vaksin di Dinkes Kabupaten petugas tidak memperhatikan rantai dingin vaksin yang dapat menurunkan kualitas dari vaksin tersebut. Hal-hal diatas dapat mempengaruhi potensi vaksin yang dimasukkan kedalam tubuh anak sehingga tidak dapat secara maksimal memberikan kekebalan pada anak.Selain itu pencatatan dan pelaporan yang tidak akurat dapat mempengaruhi informasi tentang kekebalan komunitas (Yani, 2017).

Jumlah responden responden yang menyatakan peran petugas tidak aktif terdapat 24 responden $(42,1 \%)$ dari 57 responden yang menderita campak. Hal ini di sebabkan karena pada saat penyampaian jadwal dan pelaksanaan imunisasi responden tidak berada di rumah yaitu sedang bekerja.Pada saat penyuluhan petugas dianggap tidak memberikan informasi yang baik tentang manfaat imunisasi serta gejala penyakit PD3I, karena petugas tidak menggunakan media KIE sehingga responden sulit untuk memahami manfaat imunisasi serta gejalagejala PD3I.Hal ini bila ditelaah lebih dalam disebabkan karena kualitas sumber daya petugas yang rendah.Dalam pelaksanaan imunisasi ada beberapa faktor yang menyebabkan anak tidak mendapatkan imunisasi yaitu ibu yang bekerja(Jayadipraja, Prasetya, Azlimin, \& Mando, 2018), karena kesibukan pekerjaan sehingga tidak ada waktu membawa anaknya untuk mendapatkan imunisasi pada saat jadwal posyandu. Anak juga tidak mendapatkan imunisasi karena sakit pada saat jadwal pelaksanaan Posyandu. Petugas imunisasi juga tidak melakukan sweeping pada bayi yang tidak datang di posyandu (Yani, Yuniastini, \& Fitriana, 2017)

\section{E. SIMPULAN DAN SARAN}

Simpulan pada penelitian ini adalah ada hubungan antara status Imunisasi terhadap kejadian campak di Kabupaten Muna tahun 2017, tidak ada hubungan antara peran petugas terhadap kejadian campak di Kabupaten Muna tahun 2017. Saran pada penelitian ini adalah untuk mengidentifikasi daerah dengan cakupan imunisasi rendah, meningkatkan pengetahuan masyarakat melalui 
promosi dan penyuluhan saat pelayanan posyandu tentang manfaat imunisasi dan Penyakit PD3I.

\section{DAFTAR RUJUKAN}

[1] Arianto, M., Setiawati, M., Adi, M. S., Hadisaputro, S., \& Budhi, K. (2018). Beberapa faktor risiko kejadian campak pada balita di Kabupaten Sarolangun. Jurnal Epidemiologi Kesehatan Komunitas, 3(1), 41-47

[2] Astuti, D., \& Hartini, S. (2017). Hubungan Pengetahuan dan Status Imunisasi dengan Tingkat Kejadian Campak Di Wilayah Puskesmas Kayen Kabupaten Pati. Prosiding HEFA (Health Events for All), 1(1).

[3] Arianto, M., Setiawati, M., Adi, M. S., Hadisaputro, S., \& Budhi, K. (2018). Beberapa faktor risiko kejadian campak pada balita di Kabupaten Sarolangun. Jurnal Epidemiologi Kesehatan Komunitas, 3(1), 41-47.

[4] Astuti, D., \& Hartini, S. (2017). Hubungan Pengetahuan dan Status Imunisasi dengan Tingkat Kejadian Campak Di Wilayah Puskesmas Kayen Kabupaten Pati. Prosiding HEFA (Health Events for All), 1(1).

[5] CDC. (2013). Measles - United States, January 1 - August 24 2013. 2019, from www.cdc.gov

[6] CDC. (2018). Measles Data and Statistik. 2019, from www.cdc.gov

[7] Dinkes.Kabupaten.Muna. (2018). Profil Kesehatan Kabupaten Muna. Raha: Dinas Kesehatan Kabupaten Muna.

[8] Giarsawan, N., Asmara, I. W. S., \& Yulianti, A. E. (2014). Faktor-faktor yang mempengaruhi kejadian campak di wilayah Puskesmas Tejakula I Kecamatan Tejakula Kabupaten Buleleng Tahun 2012. Jurnal kesehatan lingkungan, 4(2), 140-145.

[9] Halim, R. G. (2016). Campak pada anak. Cermin Dunia Kedokteran, 43(3), 186-189.

[10] Harisnal, H., \& Ediana, D. (2019). Determinan Kejadian Campak Pada Anak Usia Balita di Kota Bukittinggi. Jurnal Endurance, 4(1), 162. doi: 10.22216/jen.v4i1.3326. Indonesia, K. K. R. (2012). Petunjuk Teknis Surveilans Campak. Jakarta: Direktorat Jenderal Pengendalian Penyakit dan Penyehatan Lingkungan.

[11] Irianto, K. (2014). Epidemiologi Penyakit Menular Dan Tidak Menular : Panduan Klinis. Bandung: Alfabeta.

[12] Jayadipraja, E. A., Prasetya, F., Azlimin, A., \& Mando, W. O. S. Y. (2018). Family Clean And Healthy Living Behavior And Its Determinant Factors In The Village Of Labunia, Regency Of Muna, Southeast Sulawesi Province Of Indonesia. Public Health of Indonesia, 4(1), 39-45.

[13] Juliansyah Noor, S. (2016). Metodologi Penelitian: Skripsi, Tesis, Disertasi \& Karya Ilmiah: Prenada Media.

[14] Rencana Strategi Kementerian Kesehatan Tahun 2015 2019, Page 1 - 228 (2015).

[15] Kemenkes. (2018). Profil Kesehatan Indonesia 2017. Jakarta: Pusat Data dan Informasi Kementerian Kesehatan R.I.

[16] Kemenkes. (2017). Petunjuk Teknis Kampanye Imunisasi Measleas Rubella (MR). In K. K. R.I. (Ed.), (pp. Page 1 64). Jakarta.

[17] Kesehatan, M. (2005). Pedoman Penyelenggaraan Imunisasi: Depkes RI.

[18] Laelasari, E., Anwar, A., \& Soerachman, R. (2017). Evaluasi Kesiapan Pelaksanaan Program Indonesia Sehat Dengan Pendekatan Keluarga. Jurnal Ekologi Kesehatan, 16(2), 57-72.

[19] Liwu, T. S., Rampengan, N. H., \& Tatura, S. N. (2016). Hubungan status gizi dengan berat ringannya campak pada anak. e-CliniC, 4(1).

[20] Masriadi. (2017). Epidemiologi Penyakit Menular. Depok: Rajawali Press, PT Raja Grafindo Persada Persada.

[21] Mujiati, E., Mutahar, R., \& Rahmiwati, A. (2015). Faktor Risiko Kejadian Campak pada Anak Usia 1-14 Tahun di
Kecamatan Metro Pusat Provinsi Lampung Tahun 20132014. Jurnal Ilmu Kesehatan Masyarakat, 6(2).

[22] Sumantri, H. (2015). Metodologi penelitian kesehatan: Prenada Media.

[23] Tasnim, T. (2018). Determinants of Malnutrition in Children Under Five Years in Developing Countries: A Systematic Review. Indian Journal of Public Health Research \& Development, 9(6).

[24] Tramuto, F., Maida, C. M., Pojero, F., Colomba, G. M. E., Casuccio, A., Restivo, V., \& Vitale, F. (2018). Case-based surveillance of measles in Sicily during 2012-2017: The changing molecular epidemiology and implications for vaccine strategies. Plos One, 13(4), e0195256. doi: 10.1371/journal.pone.0195256

[25] Yani, S. L., Yuniastini, Y., \& Fitriana, F. (2017). HUBUNGAN STATUS IMUNISASI CAMPAK DENGAN KEJADIAN CAMPAK. Jurnal Ilmiah Keperawatan Sai Betik, 11(2), 258-261.

[26] Zakiyah, A. (2014). Hubungan antara Peran Petugas Kesehatan dengan Cakupan Imunisasi per Antigen Tingkat Puskesmas di Kabupaten Jember (Correlation between Role of Health Officer with Antigen per Immunization Coverage at Public Health Center in Jember Regency).

\section{PROFIL PENULIS UTAMA}

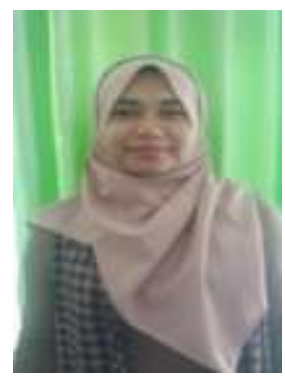

Nama: Waode Fera Falawati, SKM

Pendidikan: S1 Sekolah Tinggi IImu Kesehatan Tamalatea

Makassar (2004)

Alamat: BTN Multigraha Blok M No.1

Andonuhu Kendari 